OPEN ACCESS

Edited by:

Jens Staal,

Ghent University, Belgium

Reviewed by:

George Tsiamis,

University of Patras, Greece

David John Studholme,

University of Exeter, United Kingdom

${ }^{*}$ Correspondence:

Jose R. Botella

j.botella@uq.edu.au

Specialty section:

This article was submitted to Plant Microbe Interactions,

a section of the journal

Frontiers in Plant Science

Received: 14 August 2017

Accepted: 13 November 2017

Published: 06 December 2017

Citation:

Lau HY and Botella JR (2017) Advanced DNA-Based Point-of-Care Diagnostic Methods for Plant Diseases Detection

Front. Plant Sci. 8:2016. doi: 10.3389/fpls.2017.02016

\section{Advanced DNA-Based Point-of-Care Diagnostic Methods for Plant Diseases Detection}

\author{
Han Yih Lau' and Jose R. Botella** \\ ${ }^{1}$ Biotechnology and Nanotechnology Research Centre, Malaysian Agricultural Research and Development Institute, \\ Serdang, Malaysia, ${ }^{2}$ Plant Genetic Engineering Laboratory, School of Agriculture and Food Sciences, University of \\ Queensland, Brisbane, QLD, Australia
}

Diagnostic technologies for the detection of plant pathogens with point-of-care capability and high multiplexing ability are an essential tool in the fight to reduce the large agricultural production losses caused by plant diseases. The main desirable characteristics for such diagnostic assays are high specificity, sensitivity, reproducibility, quickness, cost efficiency and high-throughput multiplex detection capability. This article describes and discusses various DNA-based point-of care diagnostic methods for applications in plant disease detection. Polymerase chain reaction (PCR) is the most common DNA amplification technology used for detecting various plant and animal pathogens. However, subsequent to PCR based assays, several types of nucleic acid amplification technologies have been developed to achieve higher sensitivity, rapid detection as well as suitable for field applications such as loop-mediated isothermal amplification, helicase-dependent amplification, rolling circle amplification, recombinase polymerase amplification, and molecular inversion probe. The principle behind these technologies has been thoroughly discussed in several review papers; herein we emphasize the application of these technologies to detect plant pathogens by outlining the advantages and disadvantages of each technology in detail.

Keywords: point-of-care diagnostic, isothermal amplification, LAMP, HDA, RCA, RPA

\section{INTRODUCTION}

Agriculture has an estimated value of $\$ 1500$ billion US dollars (USD) per year (Agrios, 2005). However, an important amount of agricultural product is lost every year due to multiple diseases, and this problem is especially acute developing countries (Agrios, 2005; Strange, 2012) making crop disease management a priority in agriculturally based economies. In cases were resistant varieties are not available, the best option is to detect the presence of pathogens in the field as early as possible and thus avoid the onset of the disease. Hence, the effectiveness of many integrated pest management strategies are highly dependent on the availability of fast, sensitive and specific diagnostic methods. It is therefore important to develop more efficient technologies to detect crop diseases and effectively link them to decision bodies in order to efficiently deploy the necessary responses and safeguard agricultural systems. 
Many methods have been developed to identify plant pathogens (Punja et al., 2007). The earliest conventional methods used symptom observation, involving field inspections to identify disease symptoms as well as laboratory tests such as pathogen culture on selective media followed by physiological, biochemical and pathogenicity tests (Horsfall and Cowling, 1977). Although conventional methods are reliable, they are time consuming and require experienced plant pathologists to identify the pathogen responsible for the disease. These reasons made it desirable to develop detection methods with higher sensitivity, specificity and speed for plant pathogen identification.

Antibody technology has been used in plant diagnostics since the 1980s and many reviews on this technology have been published (Alvarez, 2004; Narayanasamy, 2011). Antibody-based diagnostic methods for plant pathogen detection have become popular and powerful tools because of their speed, sensitivity and inexpensive nature. However, polyclonal antibodies (PAbs) against plant pathogens produced by animal immunization may show cross-reactivity with unrelated pathogenic species due to their limited specificity (Macario and Conway de Macario, 1985). With the development of monoclonal antibodies (MAbs), specificity was improved since they target a single epitope in a pathogen protein (Thornton, 2009). Hence, various antibody-based diagnostic methods such as enzymelinked immunosorbent assays (ELISAs) (Comstock, 1992; Kokoskova and Janse, 2009), immunoblot (Novakova et al., 2006), immunofluorescent test (Malin et al., 1983) and lateral flow devices (LFD) (Tomlinson et al., 2010d) have been developed and widely used to identify plant pathogens. However, MAbs are expensive to produce and it has been reported that closely related species may share common epitopes and cause MAbs to react positively (Teitelbaum et al., 1991; Gorris et al., 1994).

The advent of the polymerase chain reaction (PCR) in the 1980 s enabled scientists to explore and develop DNAbased approaches for plant pathogen detection. As a result many PCR-based diagnostic methods for the identification of plant pathogens have been reported (Ward et al., 2004; Vincelli and Tisserat, 2008). Furthermore, the amplification of pathogen-specific sequences and the coupling of PCR with other techniques have been described in order to improve specificity and sensitivity (Merighi et al., 2000; Brasileiro et al., 2004; Carrasco-Ballesteros et al., 2007). For example highly specific immunocapture-PCR (IC-PCR) has been used for viral detection combining conventional PCR amplification with antibodycaptured viral particles. This approach increased sensitivity by 250-fold compared to direct PCR amplification (Wetzel et al., 1992) enabling successful detection of the bacterial blight disease in Anthurium propagation material (Xanthomonas axonopodis pv. dieffenbachiae) (Khoodoo et al., 2005).

A combination of conventional PCR and enzyme-linked immunosorbent assay (ELISA) termed PCR-ELISA was developed in the early 1990s (Nutman et al., 1994). The assay involves hybridization of the labeled PCR product to an immobilized probe on an ELISA plate followed by addition of an enzyme conjugate and a substrate to analyze the captured PCR product using a photometric measurement. This assay enabled the detection of a single amplicon population among several others that were generated in a multiplex reaction (Laitinen et al., 2002). This technique has been successfully used to detect viruses (Shindo et al., 1994), bacteria (Daly et al., 2002) and fungi (Bailey et al., 2002; Somai et al., 2002) with higher specificity than conventional PCR. However, despite its high specificity, the assay generated false positive results while detecting Neisseria meningitides (Borrow et al., 1998) and Mycobacterium tuberculosis (Kent et al., 1995; Gillespie et al., 1997) as the PCR amplified DNA was found to hybridize with the ELISA probe from other species.

An important improvement in DNA-based diagnostic methods came with the development of real-time quantitative PCR which allowed not only to detect the presence of pathogens but also to quantify pathogen levels in tissue samples thus allowing to determine the severity of the pathogen infection (Heid et al., 1996). A drawback of this technology is the requirements of expensive equipment and reagents which limits its use as a rapid cost-effective diagnostic method. In addition, the high sensitivity of the assay increases the risk of detecting even small amounts of contamination in the reagents or biological samples resulting in the diagnosis of false positives creating the need for normalization steps or pre-read runs to guarantee accuracy of results (Wong and Medrano, 2005; Nowrouzian et al., 2009).

Although PCR based assays have improved the sensitivity and have been used for multiplex pathogen detection (Price et al., 2010; Araujo et al., 2012; Dai et al., 2013), the assays are still prone to non-specific DNA amplification resulting in false positive results while performing multiplex detection on unknown pathogens in diseased plants tissues (Markoulatos et al., 2002; Sint et al., 2012).

\section{POINT-OF-CARE TESTING FOR PLANT PATHOGENS}

Point-of-care (POC) diagnostic assays which do not require sophisticated equipment and can be rapidly and cheaply performed in the field are in high demand (Yager et al., 2006). PCR based methods have multiple advantages over other technologies but require an electricity supply to perform the temperature changes required for DNA amplification; seriously limiting its adequacy for POC applications (Barany, 1991). As an alternative, isothermal DNA amplification methods are ideally suited to overcome this limitation (Gill and Ghaemi, 2008; Craw and Balachandran, 2012). For instance, isothermal amplification combined with lateral flow strips and portable fluorometers has been successfully used for POC detection of pathogen DNA (Notomi et al., 2000; Vincent et al., 2004; Piepenburg et al., 2006; Chow et al., 2008; Lutz et al., 2010; Mahalanabis et al., 2010; Rohrman and Richards-Kortum, 2012). Nevertheless, portable fluorometers are expensive and not necessarily suited for use in the field exposed to adverse weather conditions, thus limiting their widespread adoption. A POC diagnostic assay technology integrating the entire process from sample preparation to visualization of results is still elusive. Agricultural 
industries could greatly benefit from the availability of convenient and cheap POC assays as crop field locations can be far away from analytical laboratory setups and sample transport can pose logistical problems.

\section{POINT-OF-CARE DNA EXTRACTION METHODS}

An effective POC DNA extraction method is essential to develop rapid and user friendly molecular diagnostic assays but infield sampling is rarely discussed when describing DNA-based diagnostic methods. This non-trivial task to consistently generate a fixed DNA input of good quality (i.e., absent of potential inhibitors) has repercussions on any assays' performance. When dealing with plant tissues, the DNA extraction method requires the ability to efficiently remove a number of chemicals that can inhibit the DNA amplification reaction (Ikeda et al., 2008).

A LFD DNA extraction method has been reported as rapid and efficient for POC testing and has been successfully used in plant pathogen detection (Tomlinson et al., 2010a,b). This method involves sample disruption in extraction buffer using metal ball bearings before transferring the lysate onto the release pad of a LFD nitrocellulose membrane. A small piece of membrane is then excised and added into the DNA amplification reaction such as PCR or other isothermal amplification methods. The isolated DNA is very stable on the membrane at room temperature which allows the extraction to be performed in the field (Tomlinson et al., 2010a).

Solid Phase Reversible Immobilization (SPRI) is another DNA extraction method with potential POC application (Wee et al., 2015). A low cost DNA/RNA purification process using common filter pipette tips in conjunction with SPRI technology (Deangelis et al., 1995) to consistently extract DNA/RNA to a precise concentration that can be used immediately for downstream isothermal amplification has been recently reported (Wee et al., 2015). Magnetic SPRI bead-based extraction is ideal for POC applications because the only equipment required are a magnet and a micropipette. After macerating a single leaf disk with a plastic pestle in lysis buffer, the plant lysate was cleared of cellular debris by passing the lysate through a filtered pipette tip. DNA was then purified from the lysate using SPRI and the extracted DNA was directly used in the amplification reaction. This DNA extraction method has been used on various diagnostic applications including human and plant diseases (Ng et al., 2015; Wee et al., 2015).

A recent report has described the development of an extremely simple cellulose-based dipstick that allows plant sample processing in as little as $30 \mathrm{~s}$ (Zou et al., 2017). Plant tissues are macerated by shaking in a tube containing extraction buffer and 1-2 ball bearings for 8-10 s. A cellulose dipstick is inserted in the tube containing the sample before washing it three times in a second tube containing wash buffer and finally into the tube containing the amplification mix. The technology works efficiently in multiple cultivated species including rice, wheat tomato and sorghum as well as notoriously difficult tissues such as leaves from mature trees (mandarin, lime, and lemon). It can be used to detect pathogen DNA as well as RNA from infected tissues and works with multiple amplification methods such as PCR, LAMP, and RPA. Direct comparison studies have shown that this technology is as sensitive as SPRI but is cheaper, faster and does not require any pipetting steps.

\section{APPLICATION OF NUCLEIC ACID ISOTHERMAL AMPLIFICATION TECHNIQUES IN PLANT DISEASE DETECTION}

Enzyme mediated in vitro amplification of nucleic acids has become an essential tool in molecular biology since 1980's (White et al., 1989). PCR is one of the most widely used methods for the detection and identification of pathogens by targeting specific sequences in their genomic DNA. Although PCR is highly sensitive and robust, it is constrained by a number of technical limitations. For instance, specificity is highly dependent on the primers used and its inherent sensitivity makes it prone to false positives due to sample cross-contamination. Besides, PCR also requires electrically powered equipment to perform the thermal cycling which limits its use for point-of-care diagnostics. A number of alternative isothermal techniques are now available that can obviate the need for a thermal cycler although each has strengths and weaknesses.

\section{LAMP}

Loop-mediated isothermal amplification (LAMP) is a nucleic acid amplification method developed in Notomi et al. (2000). It has been widely used due to its high efficiency, specificity, simplicity and quickness. LAMP requires two long outer primers and two short inner primers that recognize six specific sequences in the target DNA. The first inner primer containing sense and antisense sequences in the DNA will hybridize the target sequence and initiate DNA synthesis (Figure 1; Tomita et al., 2008). Next, the outer primer carries out the strand-displacement DNA synthesis and produces a single stranded DNA which works as a template for the second inner and outer primers producing a DNA molecule with a loop structure. The unremitting cycling reaction accumulates products with repeated sequences of target DNA of different sizes.

Loop-mediated isothermal amplification has three major advantages. Firstly, it can be carried out at a constant temperature with a short reaction time. This rapid isothermal process makes it ideal for point-of-care detection of plant pathogens in the field (Fukuta et al., 2014) and has been used to detect the plum pox virus in $2.5 \mathrm{~h}$ (Hadersdorfer et al., 2011). Secondly, it has very high amplification efficiency and sensitivity as it generates large amounts of PCR product with low amounts of input DNA (Tomlinson et al., 2010c; Bhat et al., 2013). Finally, this method is relatively cost effective as it requires simple equipment to perform the assay. Furthermore, there have been reports stating that LAMP generates amplicons with several inverted repeats which could be potentially used to increase the sensitivity in hybridization assays, such as LAMP-ELISA hybridization (Lee 


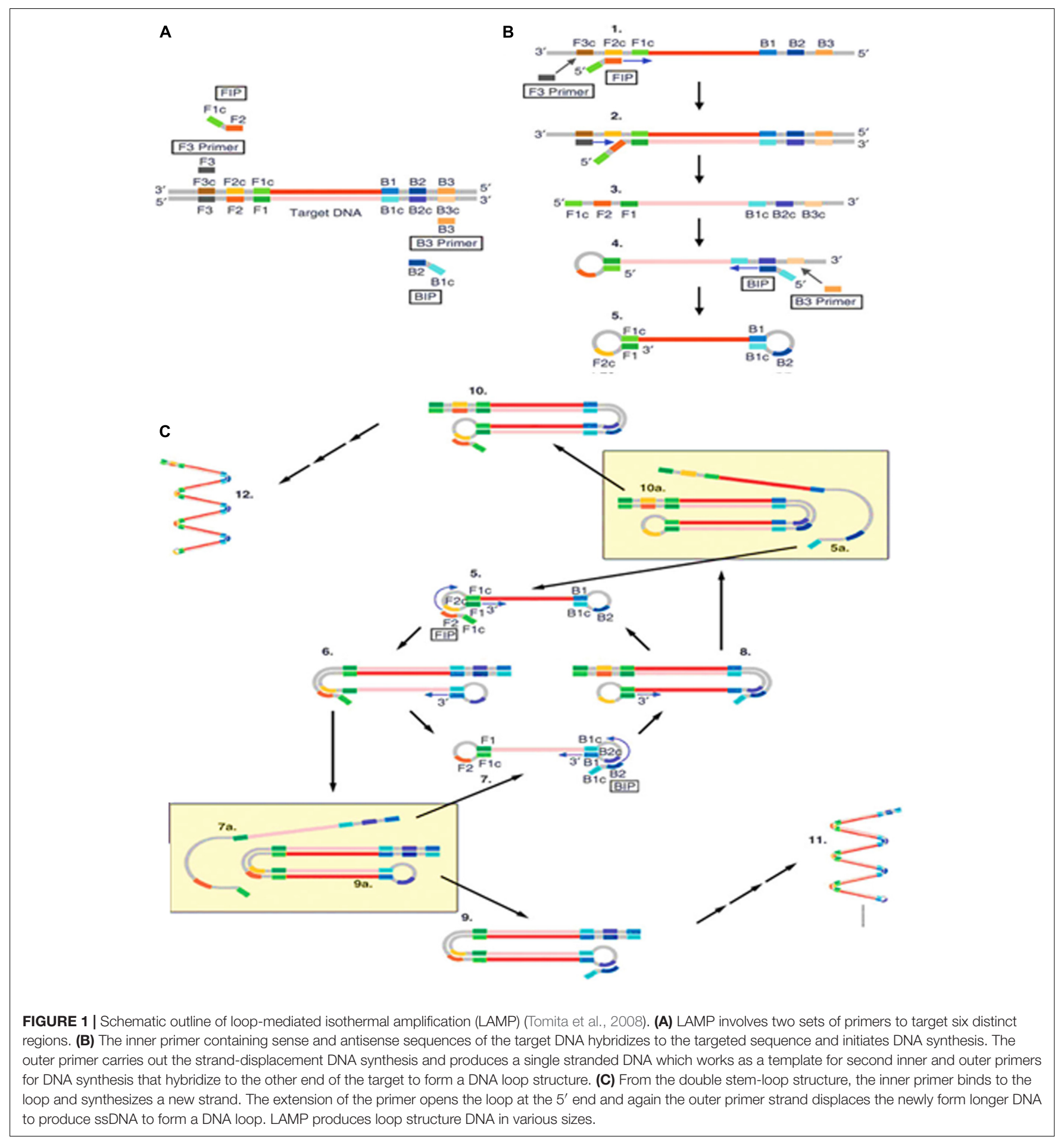

et al., 2014) and LAMP incorporated with colorimetric gold nanoparticle hybridization probes (Watthanapanpituck et al., 2014).

Although LAMP is an ideal isothermal method for in field POC plant pathogen detection, it does possess certain limitations. Firstly, the design of the LAMP primers is complicated and nonintuitive, making it difficult for non-specialists. Even though there is available software for LAMP primer design, optimal primers performance is not guaranteed as it is usually the case for PCR. In addition, LAMP amplicons contain a mixture of stemloop DNA molecules of different sizes which are not suitable for gene cloning purposes or to identify specific targets based on size differences. However, the size limitation was overcome by Nagamine et al. (2002) who developed a modified LAMP method 
that generates uniform and single stranded DNA amplicons through TspRI digestion before extending the products using a primer to produce strand-specific DNA fragments.

Since LAMP has potential for POC diagnostic purposes, several simple read-out methods have been combined with LAMP to replace the traditional gel electrophoresis analysis in order to detect the presence of amplicons. The simplest and cheapest methods use metal-ion indicators such as hydroxynaphthol blue (HNB) or SYBR green as DNA dyes to visualize the final products (Chen et al., 2012; Duan et al., 2014). By adding color indicators into the LAMP reaction prior to amplification, the products can be detected by the naked eye using a simple colorimetric assay. Using this read-out method, it was possible to detect as low as 10 copies of target DNA (Chen et al., 2012). The colorimetric readout has been successfully used for naked-eye detection of potato leafroll virus and Fusarium oxysporum (Ahmadi et al., 2013; Zhang et al., 2013). Nevertheless, in our experience the color changes induced by the abovementioned indicators can be quite subtle and, even though they might be possible to observe in a laboratory environment, they are difficult to detect in the field due to the different light conditions at different times of the day.

Alternatively, LAMP has been combined with ELISA by incorporating antigen-labeled nucleotides into the LAMP amplicons during the amplification process. The generated amplicons are then hybridized to specific immobilized oligonucleotide probes which are later analyzed by immunoassay. The main advantage of LAMP-ELISA is its ability to process hundreds of samples simultaneously within a few hours (Ravan and Yazdanparast, 2012; Lee et al., 2014). The combination of LAMP with ELISA provides very high sensitivity with a single copy of target DNA being successfully detected (Lee et al., 2014). However, this technique requires skilled labor as it involves complicated ELISA steps.

Following the use of optical and colorimetric readout systems, electrochemical sensors capable of detecting signal changes caused by the electron transfer in double stranded DNA have been used to detect the presence of amplified DNA (Ferguson et al., 2009). The integration of LAMP with the electrochemical sensor offered a robust platform for pathogen detection as it was highly sensitive, detecting as low as 10 copies of pathogen genomic DNA (Hsieh et al., 2012). The applications of LAMPbiosensor technology are increasing in all fields, from clinical molecular diagnostics to environmental monitoring, but its application is still fairly new in plant pathogen detection. Therefore, LAMP-biosensor technology has a strong potential for in field testing, detection and identification of plant diseases.

\section{HDA}

Helicase dependent amplification (HDA) is an alternative isothermal technique developed by New England Biolabs in 2004 (Vincent et al., 2004). This isothermal technique is very similar to the standard PCR but it does not require heat denaturation to separate the double stranded DNA and allows primers to anneal to its complementary target sequences. HDA uses DNA helicase to generate single stranded DNA for primer annealing followed by primer extension at isothermal conditions (Figure 2). Single stranded binding protein (SSB) and MutL endonuclease are added to the reaction to prevent rehybridization of complementary ssDNA strands to reform the dsDNA. Detectable amounts of PCR amplicons for downstream analysis are generally generated within $60 \mathrm{~min}$ by the HDA method (Vincent et al., 2004).

Helicase dependent amplification has become a popular isothermal technique due to its simple reaction steps. Although it amplifies the target sequences using a pair of primers using the same principle as PCR, the steps are much simpler as it does not need multiple temperature cycling steps. Although LAMP and had are both isothermal, LAMP requires four intricately designed long primers which need an initial heat denaturation step before amplification at a lower temperature (Nagamine et al., 2002). HDA has been successfully used to detect pathogen genomic DNA present in a crude mixture of human blood sample with high sensitivity (Vincent et al., 2004). Although HDA's characteristics seem perfect for the development of simple point of care diagnostic assays, the main drawback is that it requires complex optimization to ensure a coordinated enzyme activity between the helicase and DNA polymerase.

Additionally, the presence of SSB and MutL, which are essential to prevent ssDNA from re-hybridizing to form dsDNA can potentially affect the final results significantly (Vincent et al., 2004). Furthermore, there are some reports stating that HDA is inefficient when amplifying long targets (Guatelli et al., 1990), probably due to the fact that the UvrD helicase has limited unwinding speed $(20 \mathrm{bp} / \mathrm{s})$ and process less than $100 \mathrm{bp}$ per binding (Ail et al., 1999). MutL is able to enhance the UvrD unwinding activity but does not increase the processing rate (Mechanic et al., 2000). A significant improvement has been made with the discovery of a thermostable UvrD helicase (Tte-UvrD) from Thermoanaerobacter tengcongensis suitable for amplification at a higher temperature (An et al., 2005). The use of Tte-UvrD allows HDA to be performed at a higher temperature, decreasing the re-annealing of single stranded DNA and therefore obviating the need for SSB and MutL.

Currently, HDA is commonly used in human clinical applications such as the diagnosis of Salmonella paratyphi (Faizul Rahman et al., 2014) and diarrhea-causing pathogens (Huang et al., 2013; Eckert et al., 2014), as well as veterinary applications such as detection of Streptococcus equi causing strangles in horses (Artiushin et al., 2011). However, its application to plant pathogen detection is still limited and has only been used to identify citrus leprosis virus $\mathrm{C}$ and tobacco mosaic virus (Corona et al., 2010). In order to improve sensitivity, HDA has been combined with other technologies such as ELISA (Gill et al., 2007) and gold nanoparticles (Gill et al., 2008) to detect Helicobacter pylori. The results of both HDA-ELISA and HDAnanoparticles showed a $90 \%$ increase in sensitivity and specificity compared to the original HDA assay.

\section{RCA}

The principle of isothermal amplification has been also used to amplify circular DNA in a process known as rolling circle amplification (RCA) (Fire and Xu, 1995). RCA involves using a DNA polymerase with strand displacement activity (such as 


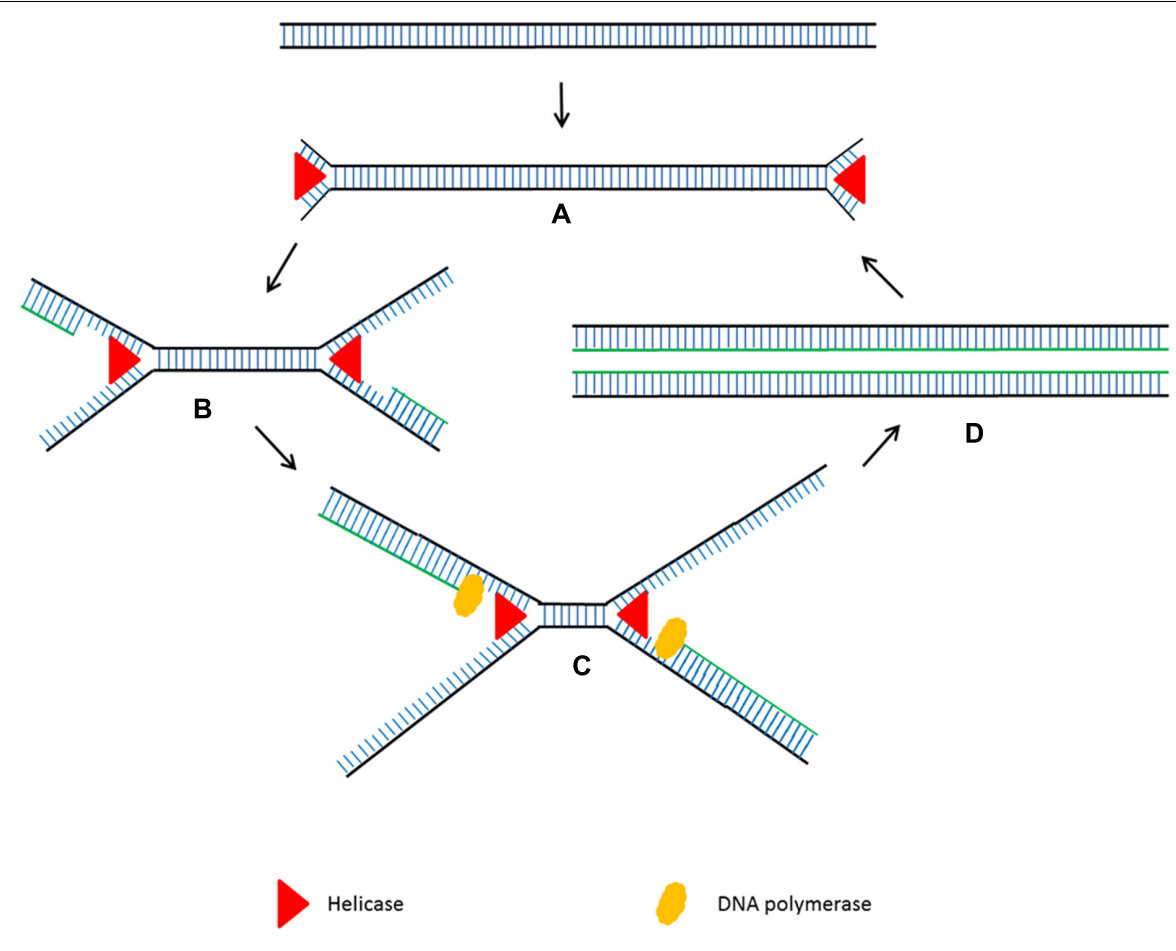

FIGURE 2 | Schematic outline of helicase dependent amplification (HDA). (A) Helicase opens the dsDNA. (B) The primers anneal to the target sequences. (C) Primer extension by DNA polymerase. The newly formed dsDNAs are opened by helicase and the process starts again. (D) The newly formed dsDNAs are opened by helicase and the process starts again.

$\phi 29$ DNA polymerase) to extend a single primer annealed to a circular DNA template. The strand displacement activity allows the newly synthesized DNA to displace the previously generated DNA releasing ssDNA (Blanco et al., 1989). This enzymatic process of primer extension combined with strand displacement generates a long single stranded DNA containing a repeated sequence complementary to the circular template (Figure 3).

Rolling circle amplification offers the simplest available isothermal reaction mechanism. With additional manipulation, linear DNA is also suitable as a template for the RCA reaction. A linear ssDNA probe can be designed in such a way that it can be initially hybridized to the target sequence forming a loop and ligated to form a circular probe prior to performing RCA (Figure 4). This process, termed padlock probe assay, has been used in the detection of many plant diseases (Szemes et al., 2005; Slawiak et al., 2013; Tian et al., 2014). The high multiplexing potential and specificity of padlock probes followed by RCA also contributes to its popularity in multiplex detection of plant pathogens. In addition, RCA has been reported to have higher specificity and be less prone to non-specific amplification than PCR. Another advantage of the RCA method is that it allows to generate up to 0.5 megabases of DNA per probe in an overnight incubation (Baner et al., 1998) and generates $10^{9}$ or more copies of each circle in $90 \mathrm{~min}$ (Lizardi et al., 1998). Generating multiple copies of repetitive sequences offer an advantage in hybridization based readouts where the repetitive sequences can be easily captured to increase the sensitivity (Gusev et al., 2001; Nallur et al., 2001; Russell et al., 2014). Furthermore, RCA is resistant, or at least less prone to carry-over contamination of the amplification products because there is no new $3^{\prime}$-end ssDNA product generated throughout the RCA process, which could be a potential primer for non-specific amplification (Kobori and Takahashi, 2014).

Rolling circle amplification has been widely used for plant pathogen detection since early 2000s. Several techniques have been used in combination with RCA such as restriction fragment length polymorphism (RFLP) and direct sequencing to identify and classify plant pathogen efficiently with significantly lower effort and cost than conventional technologies (Schubert et al., 2007). Visualization of RCA products using naked eye by adding fluorescent dye has been used to detect more than 40 strains of Fusarium spp. (Davari et al., 2012). Ligation of padlock probes followed by RCA has also been developed for identification of fungal pathogens (Najafzadeh et al., 2011). Incorporating RCA with a variety of readout technologies such as microarrays, DNA biosensors and immune assays has significantly improved the sensitivity when compared to gel electrophoresis (Gusev et al., 2001; Nallur et al., 2001; Li et al., 2009; Ji et al., 2012; Russell et al., 2014). Although these read out methods seem as an ideal alternative for RCA based assays, they are expensive and involve complicated steps compared to simple monitoring a color change using naked eye.

\section{RPA}

Recombinase polymerase amplification (RPA) is another isothermal technique that, like HDA, does not require an initial 

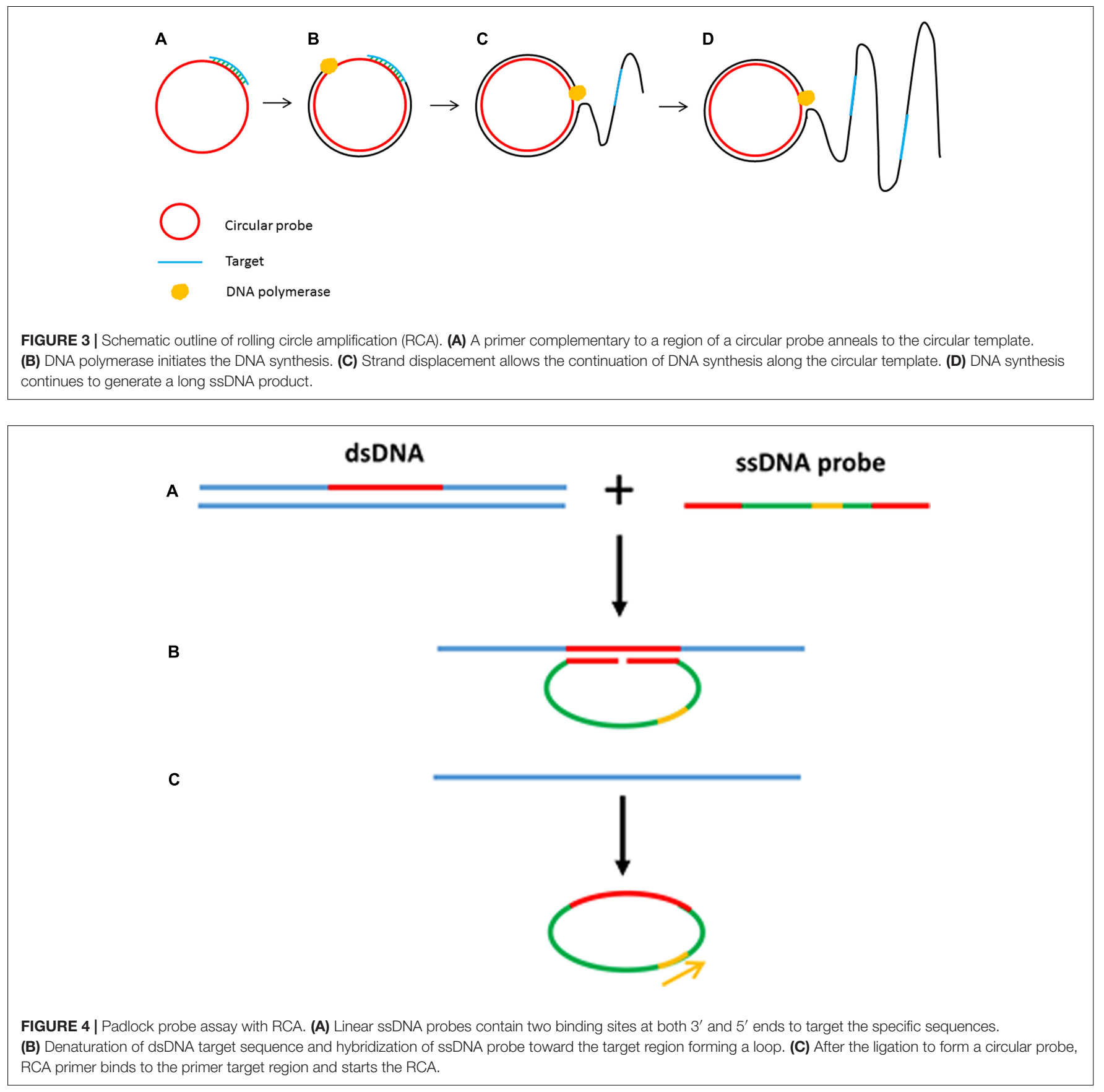

heating step to denature the target DNA (Piepenburg et al., 2006) as it relies on an enzymatic activity to separate the dsDNA in order to assist primer binding to the target sequences. The reaction begins with the integration of a recombinase protein with the primers prior to their annealing to specific sequences in the target. Following primer annealing, the recombinase dissociates from the primers and leaves their $3^{\prime}$ end accessible to the DNA polymerase to initiate the amplification. This creates a d-loop which is stabilized by a single stranded binding protein (SSB) to keep the DNA open as a DNA polymerase with strand displacement activity continues the amplification (Figure 5).
Using RPA, billions of DNA copies can be generated efficiently in 60 min with an incubation temperature between $37^{\circ} \mathrm{C}$ and $42^{\circ} \mathrm{C}$ (Piepenburg et al., 2006).

The low incubation temperature and short reaction time (15$30 \mathrm{~min}$ ) make RPA a suitable assay for use in point-of-care diagnostic applications. Furthermore, primer design is simple without consideration of annealing temperature as they form a complex with the recombinase to target the homologous sequences. RPA is highly sensitive with a detection limit as low as $6.25 \mathrm{fg}$ of genomic DNA input with a specificity $>95 \%$ (Boyle D.S. et al., 2014). 


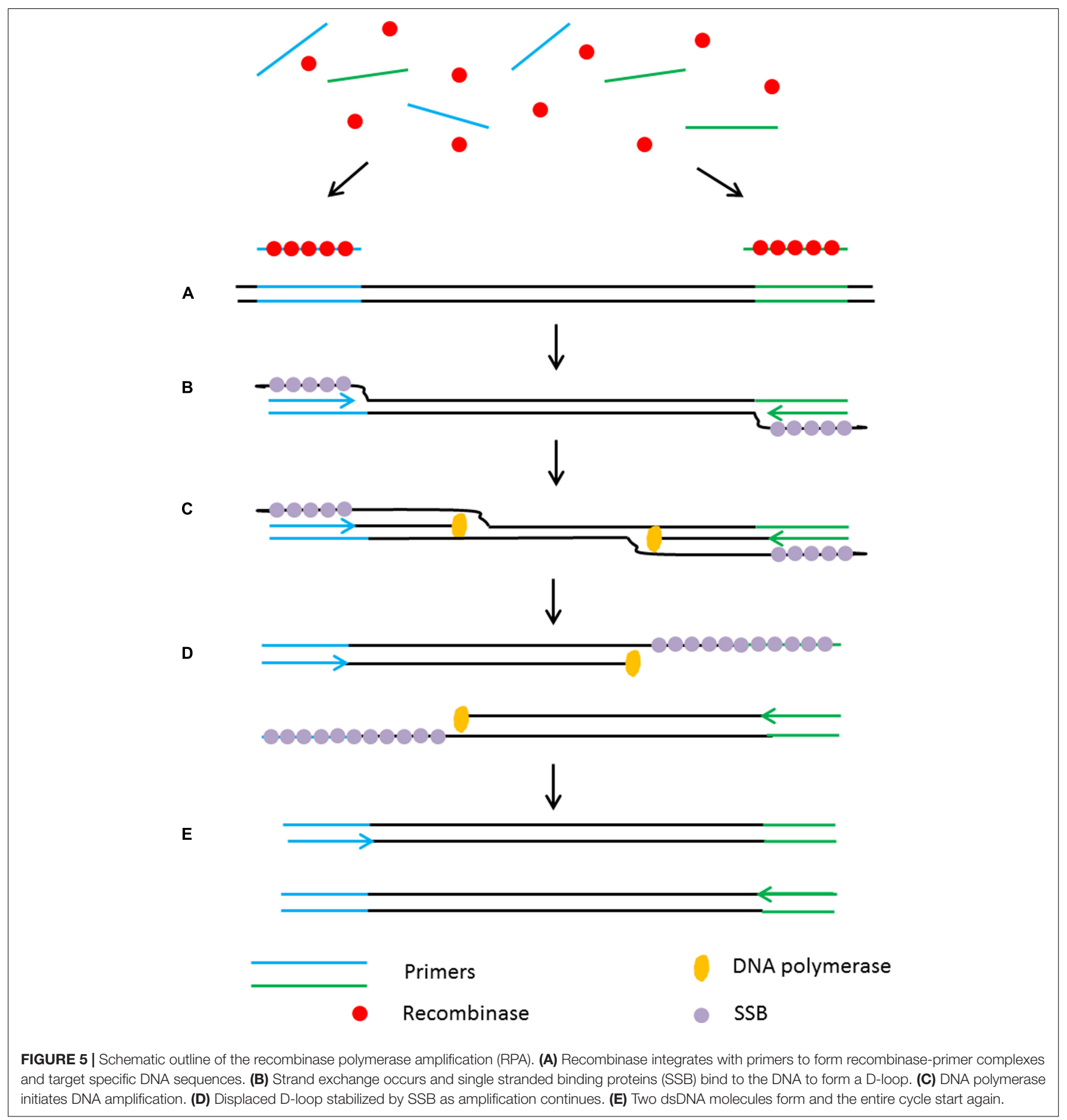

However, as with the other discussed technologies, RPA has some drawbacks as it can only amplify small DNA fragments $(<500 \mathrm{bp})$, therefore it is not suitable in cases where amplification of full length genes is required. In addition, the longer primers (30-35 nt) required for RPA are prone to produce non-specific amplification at low temperature. Furthermore, the primers used in the RPA reaction frequently generate high background noise on negative and non-template control samples due to the formation of primer dimers thus affecting the sensitivity of the assay.

Many reports describing clinical RPA-based applications have been recently published (Boyle D.S. et al., 2014; Crannell et al., 2014; Kersting et al., 2014). In plants, a number of RPA-based applications have been described to detect plant pathogens with high sensitivity, specificity and cost effectiveness. A combination 
of reverse transcriptase-RPA (RT-RPA) and lateral flow has successfully detected little cherry virus from crude extracts being more cost effective than RT-PCR and more suitable for resource limited settings (Mekuria et al., 2014). RT-RPA has also been used to detect plum pox virus with higher sensitivity than conventional ELISA and immunostrip (Zhang et al., 2014). RPA-ELISA has been developed for sensitive, specific and costeffective identification of plant pathogens (Santiago-Felipe et al., 2014). A naked eye assay which couples RPA with bridging flocculation of magnetic beads has been recently developed for efficient POC detection of plant and human pathogens (Ng et al., 2015; Wee et al., 2015). RPA followed by DNA electrochemical sensor as a readout platform has been reported as a new technology for plant pathogen detection (Lau et al., 2017). This RPA/electrochemical sensor is 10,000 times more sensitive than conventional polymerase chain reaction (PCR)/gel electrophoresis and it has successfully identified Pseudomonas syringae infected plant samples at an early infection stage before any symptoms are visible. Given that RPA is a fairly new isothermal technique, there is still more exploration to be done for point-of-care detection of plant pathogens.

\section{MULTIPLEX DETECTION OF PLANT PATHOGENS}

Development of technologies with multiplex detection capability is another challenge in plant disease diagnostics as they are more cost effective, reduce assay time and require minimal amount of sample. High throughput multiplex detection has been successfully achieved using real-time PCR on an OpenArray ${ }^{\mathrm{TM}}$ platform (van Doorn et al., 2007), microsphere immunoassay technology (Charlermroj et al., 2013) and microarrays (Szemes et al., 2005). However, simpler but efficient multiplex detection methods capable to identify multiple pathogens simultaneously are still needed.

Molecular inversion probes (MIPs) enable cost effective multiplex diagnostics and has been often used in clinical applications. MIP is a long single stranded probe in excess of $>100 \mathrm{nt}$ long with two binding domains at the $5^{\prime}$ and $3^{\prime}$ ends (B1 and B2 in Figure 6). The binding domains are designed to be complementary to the target region of interest (Figure 6; Lau et al., 2014). This enables the MIP to form a circular loop with a single stranded gap in between the two binding regions. After annealing of the MIP, a DNA polymerase lacking $5^{\prime}-3^{\prime}$ exonuclease and strand displacement activities initiates DNA synthesis from the $3^{\prime}$ end of the gap in a gap-fill reaction. DNA ligase is then used to ligate the newly synthesized strand and generate a circular DNA molecule. To ensure the sensitivity of the assay, an exonuclease digestion step is performed to remove the linear probes. The ligated MIPs are then amplified in a PCR reaction using a universal primer set targeted $\mathrm{P} 1$ and $\mathrm{P} 2$.

The highly multiplexable nature of MIP probes, which are able to distinguish thousands of targets in a single reaction is a major advantage of this assay. The binding domains at the $3^{\prime}$ and $5^{\prime}$ ends are connected by a DNA backbone; this design feature physically restricts the binding domains to a small

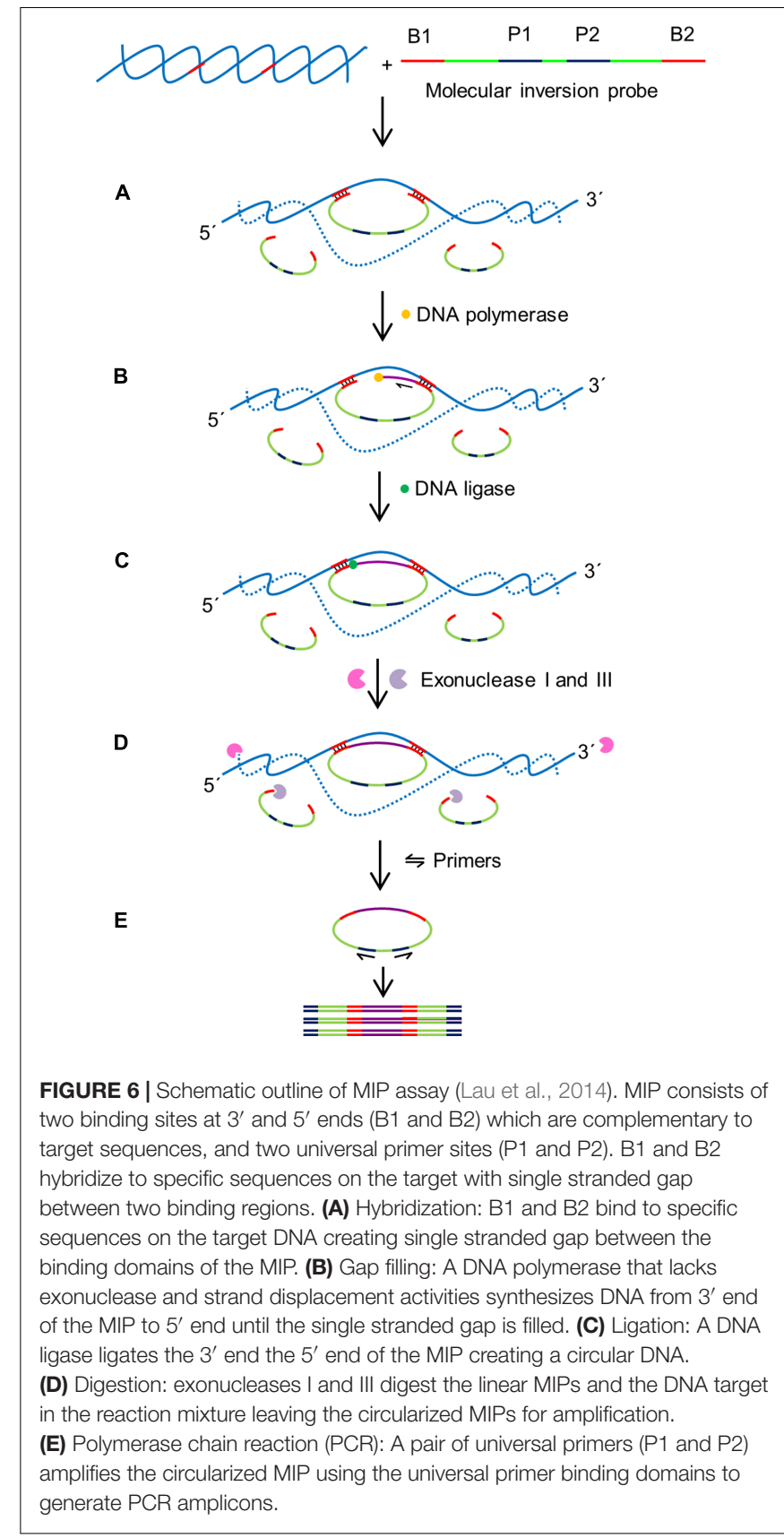

region of the genome that needs to contain both recognition sequences, dramatically increasing the specificity of the MIP assays. In addition, the noise signal of the assay is decreased by enzymatically degrading the non-ligated linear MIPs by the exonuclease digestion with up to $99 \%$ efficiency. MIPs have been designed to detect up to 330000 targets in a single reaction (Diep et al., 2012). The MIP multiplexing capability has been demonstrated in various clinical studies such as high-throughput analysis of single nucleotide polymorphisms, DNA methylation, detection of genomic copy number changes and other genotyping applications (Hardenbol et al., 2003; Wang et al., 2005; Diep et al., 2012). However, applications for plant diagnostics are still 
limited with the first report describing the successful detection of Fusarium oxysporum f.sp. conglutinans in infected Arabidopsis thaliana with a detection limit of $2.5 \mathrm{ng}$ (Lau et al., 2014). In order to improve the efficiency of MIP assays, the MIPgen software has been developed for the design and performance prediction of individual MIPs (Boyle E.A. et al., 2014).

Serious limitations of these assays are the requirement for several temperature settings throughout the assay and a tedious yet complicated experimental process that makes it unsuitable for POC testing. Besides, the assay is time consuming taking in excess of $10 \mathrm{~h}$ to complete a reaction, making MIP assays only suitable for applications in the laboratory. MIPs with lengths of $>100$ bp require HPLC purification which increases the cost of oligonucleotide synthesis. Achieving a high level of multiplex detection involving thousands of MIPs in a single reaction requires a large initial investment. In addition, multiplex detection using MIP assays needs a complex read-out platform such as next generation sequencing, microarrays or biosensors (Lin et al., 2010; Wang et al., 2012; Carrascosa et al., 2014) further increasing the cost of the assay.

A recently published method using a combination of RPA and surface enhanced Raman scattering (SERS) has described the possibility of multiplex detection of plant pathogens in the field (Lau et al., 2016). Surface-enhanced Raman scattering (SERS) is a technique that provides enhanced Raman scattering patterns of the adsorbed molecules from metal nanoparticles surfaces upon a single laser excitation (Schlucker, 2014). SERS has been reported as a potentially powerful molecular spectroscopy detection tool (Moskovits, 2010), and a highly promising readout technology for rapid diagnostic assays (Anker et al., 2008; Bantz et al., 2011; Sharma et al., 2012). SERS produces narrow and distinct spectral peaks which provides higher precision after analysis compared to the standard fluorescent-based methods for highly multiplexed applications (Schlucker, 2009; Wang and Schlucker, 2013; Laing et al., 2016). Furthermore, SERS using different Raman reporters have enabled multiplex detection (Lai et al., 2015) especially in clinical applications (Maiti et al., 2011; Wang et al., 2015). The first report incorporating SERS with multiplex RPA for agricultural applications has appeared in 2016, detecting several plant pathogens (Lau et al., 2016). The technique has been successfully used to detect Botrytis cinerea in infected tomato plants in a field situation. Although this technique is ready for field application, it involves an expensive portable SERS reader which might limits its application.

\section{DISCUSSION AND CONCLUSION}

The main benefit of POC diagnostic testing is to provide rapid results in situ, enabling farmers to make immediate management decisions and minimize crop loses. An additional advantage is the reduction in logistic problems associated with sample transportation to centralized laboratories for disease analysis and the concomitant labor costs. POC diagnostic kits should be portable and user friendly allowing a single operator with no specialized scientific skills to carry out the test. In this paper, some of the commonly used nucleic acid-based methods for plant pathogen detection were discussed. Although the vast majority of current applications are PCR-based, numerous research reports have established that the existing isothermal techniques can perform as well as or even better than PCR-based assays. The ability to perform reactions at a constant temperature makes isothermal techniques promising candidates for point-of-care diagnostic assays in low resource settings. Each of the isothermal and non-isothermal technologies discussed here has inherent advantages and limitations therefore the choice on the best technology to adopt will depend on the specific problem; i.e., the nature of the pathogen, the crop being monitored and the technological capability of the country.

Among the available isothermal techniques, LAMP and RCA are the best candidates for hybridization based applications because the repeated sequences present in the amplification products are able to increase detection sensitivity (Gusev et al., 2001; Nallur et al., 2001; Hsieh et al., 2012). However, both techniques produce isothermal amplification products in various sizes and are therefore not suitable for applications where a specific DNA fragment size is needed for identification. HDA and RPA isothermal technologies do not require a heat denaturation step and as a result can be performed directly at a constant temperature, a big advantage for field applications. Nevertheless, HDA and RPA are limited to targets shorter than 100 and $500 \mathrm{bp}$, respectively. Furthermore, despite the sensitivity and specificity of these isothermal techniques, they are not highly multiplexable, limiting their application to the detection of a single, or at best a limited number of pathogens in a single assay. To achieve the multiplex detection of plant pathogens, MIP is a promising method which can provide high specificity but its application in the field is quite limited due to its technical complexity. The development of RPA-SERS technology allows multiplex field detection to be performed within $90 \mathrm{~min}$ at a single constant low temperature $\left(37^{\circ} \mathrm{C}\right)$ with high sensitivity and specificity, however, portable SERS readers are expensive.

Next generation sequencing (NGS) technologies have a huge potential in the diagnostic space as they can identify multiple pathogens in a single analysis without any previous knowledge of their nature (Massart et al., 2014; Withers et al., 2016; Rott et al., 2017). Nevertheless, they still need to overcome a number of limitations before they can be used for POC applications. NGS equipment is quite sophisticated, requiring a clean laboratory environment as well as a reliable power supply. Sample preparation for analysis is quite complex, requiring multiple steps, pipetting of small volumes, occasional use of centrifuges and final quality checks using bio-analyzing equipment. Finally, the current cost of NGS sequencing technologies, in the range of hundreds or thousands of dollars, is too high for POC routine diagnostic analyses although future developments might make them affordable for this type of applications.

In summary, traditional laboratory methods are accurate but labor intensive and slow and, most importantly, need highly specialized technical personnel. Unfortunately the availability of skilled plant pathologists is becoming a problem worldwide (Horsfall and Cowling, 1977). Antibody-based diagnostic 
methods are clearly faster than traditional techniques but specificity of detection can be sometimes strongly compromised due to cross reactivity resulting in erroneous pathogen identification (Franken et al., 1992). The limitations of antibodybased methods are further compounded by their short shelf life and batch to batch variability (Murphy et al., 2012). Nucleic acid-based methods provide higher specificity and have the potential to solve many of the problems experienced in antibodybased diagnostics (Ward et al., 2004; Vincelli and Tisserat, 2008; Hindson et al., 2011; Miotke et al., 2014). PCR is the most popular DNA-based identification technique for plant pathogens but it needs a power supply to achieve the continuous changes in temperature that are crucial for this technology to work, limiting its suitability for POC field applications (Markoulatos et al., 2002; Sint et al., 2012). Isothermal amplification systems can address this limitation and provide better sensitivity, specificity as well as capability in POC applications either by themselves or coupled with other technologies such as rapid readout methods to analyse the DNA amplification products.

\section{REFERENCES}

Agrios, G. N. (2005). Plant Pathology. Amsterdam: Elsevier Academic Press.

Ahmadi, S., Almasi, M. A., Fatehi, F., Struik, P. C., and Moradi, A. (2013). Visual detection of potato leafroll virus by one-step reverse transcription loopmediated isothermal amplification of DNA with hydroxynaphthol blue dye. J. Phytopathol. 161, 120-124. doi: 10.1111/jph.12037

Ail, J. A., Maluf, N. K., and Lohman, T. M. (1999). An oligomeric form of E-coli UvrD is required for optimal helicase activity. J. Mol. Biol. 293, 815-834. doi: 10.1006/jmbi.1999.3185

Alvarez, A. M. (2004). Integrated approaches for detection of plant pathogenic bacteria and diagnosis of bacterial diseases. Annu. Rev. Phytopathol. 42, 339-366. doi: 10.1146/annurev.phyto.42.040803.140329

An, L. X., Tang, W., Ranalli, T. A., Kim, H. J., Wytiaz, J., and Kong, H. M. (2005). Characterization of a thermostable UvrD helicase and its participation in helicase-dependent amplification. J. Biol. Chem. 280, 28952-28958. doi: 10. 1074/jbc.M503096200

Anker, J. N., Hall, W. P., Lyandres, O., Shah, N. C., Zhao, J., and Van Duyne, R. P. (2008). Biosensing with plasmonic nanosensors. Nat. Mater. 7, 442-453. doi: $10.1038 /$ nmat 2162

Araujo, R., Amorim, A., and Gusmao, L. (2012). Diversity and specificity of microsatellites within Aspergillus section Fumigati. BMC Microbiol. 12:154. doi: $10.1186 / 1471-2180-12-154$

Artiushin, S., Tong, Y. H., Timoney, J., Lemieux, B., Schlegel, A., and Kong, H. M. (2011). Thermophilic helicase-dependent DNA amplification using the IsoAmp (TM) SE experimental kit for rapid detection of Streptococcus equi subspecies equi in clinical samples. J. Vet. Diagn. Invest. 23, 909-914. doi: $10.1177 / 1040638711416968$

Bailey, A. M., Mitchell, D. J., Manjunath, K. L., Nolasco, G., and Niblett, C. L. (2002). Identification to the species level of the plant pathogens Phytophthora and Pythium by using unique sequences of the ITS1 region of ribosomal DNA as capture probes for PCR ELISA. FEMS Microbiol. Lett. 207, 153-158. doi: 10.1111/j.1574-6968.2002.tb11044.x

Baner, J., Nilsson, M., Mendel-Hartvig, M., and Landegren, U. (1998). Signal amplification of padlock probes by rolling circle replication. Nucleic Acids Res. 26, 5073-5078. doi: 10.1093/nar/26.22.5073

Bantz, K. C., Meyer, A. F., Wittenberg, N. J., Im, H., Kurtulus, O., Lee, S. H., et al. (2011). Recent progress in SERS biosensing. Phys. Chem. Chem. Phys. 13, 11551-11567. doi: 10.1039/c0cp01841d

Barany, F. (1991). The ligase chain reaction in a PCR world. PCR Methods Appl. 1, 5-16. doi: 10.1101/gr.1.1.5

Bhat, A. I., Siljo, A., and Deeshma, K. P. (2013). Rapid detection of Piper yellow mottle virus and Cucumber mosaic virus infecting black pepper (Piper nigrum)

\section{AUTHOR CONTRIBUTIONS}

All authors listed have made a substantial, direct and intellectual contribution to the work, and approved it for publication.

\section{FUNDING}

The authors would like to thank Malaysian Agricultural Research and Development Institute (MARDI) for providing the Ph.D. scholarship of HYL.

\section{ACKNOWLEDGMENTS}

Special thank goes to Dr. Indu B. Jaganath from MARDI for editing the manuscript and helpful review. The authors also acknowledge Dr. Norihiro Tomita for the permission to use the schematic of LAMP in Figure 1.

by loop-mediated isothermal amplification (LAMP). J. Virol. Methods 193, 190-196. doi: 10.1016/j.jviromet.2013.06.012

Blanco, L., Bernad, A., Lazaro, J. M., Martin, G., Garmendia, C., and Salas, M. (1989). Highly efficient DNA-synthesis by the phage Phi-29 DNApolymerase - symmetrical mode of DNA-replication. J. Biol. Chem. 264, 8935-8940.

Borrow, R., Guiver, M., Sadler, F., Kaczmarski, E. B., and Fox, A. J. (1998). False positive diagnosis of meningococcal infection by the IS1106 PCR ELISA. FEMS Microbiol. Lett. 162, 215-218. doi: 10.1111/j.1574-6968.1998. tb13001.x

Boyle, D. S., Mcnerney, R., Low, H. T., Leader, B. T., Perez-Osorio, A. C., Meyer, J. C., et al. (2014). Rapid detection of Mycobacterium tuberculosis by recombinase polymerase amplification. PLOS ONE 9:e103091. doi: 10.1371/ journal.pone.0103091

Boyle, E. A., O'roak, B. J., Martin, B. K., Kumar, A., and Shendure, J. (2014). MIPgen: optimized modeling and design of molecular inversion probes for targeted resequencing. Bioinformatics 30, 2670-2672. doi: 10.1093/ bioinformatics/btu353

Brasileiro, B. T. R. V., Coimbra, M. R. M., De Morais, M. A., and De Oliveira, N. T. (2004). Genetic variability within Fusarium solani specie as revealed by PCR-fingerprinting based on PCR markers. Braz. J. Microbiol. 35, 205-210. doi: 10.1590/S1517-83822004000200006

Carrasco-Ballesteros, S., Castillo, P., Adams, B. J., and Perez-Artes, E. (2007). Identification of Pratylenchus thornei, the cereal and legume root-lesion nematode, based on SCAR-PCR and satellite DNA. Eur. J. Plant Pathol. 118, 115-125. doi: 10.1007/s10658-007-9110-3

Carrascosa, L. G., Ibn Sina, A., Palanisamy, R., Sepulveda, B., Otte, M. A., Rauf, S., et al. (2014). Molecular inversion probe-based SPR biosensing for specific, labelfree and real-time detection of regional DNA methylation. Chem. Commun. 50, 3585-3588. doi: 10.1039/c3cc49607d

Charlermroj, R., Himananto, O., Seepiban, C., Kumpoosiri, M., Warin, N., Oplatowska, M., et al. (2013). Multiplex detection of plant pathogens using a microsphere immunoassay technology. PLOS ONE 8:e62344. doi: 10.1371/ journal.pone.0062344

Chen, X. Y., Wang, X. F., Jin, N., Zhou, Y., Huang, S. A., Miao, Q. M., et al. (2012). Endpoint visual detection of three genetically modified rice events by loop-mediated isothermal amplification. Int. J. Mol. Sci. 13, 14421-14433. doi: 10.3390/ijms131114421

Chow, W. H. A., Mccloskey, C., Tong, Y. H., Hu, L., You, Q. M., Kelly, C. P., et al. (2008). Application of isothermal helicase-dependent amplification with a disposable detection device in a simple sensitive stool test for toxigenic Clostridium difficile. J. Mol. Diagn. 10, 452-458. doi: 10.2353/jmoldx.2008. 080008 
Comstock, J. C. (1992). Detection of the sugarcane leaf scald pathogen, Xanthomonas-Albilineans, using tissue blot immunoassay, elisa, and isolation techniques. Plant Dis. 76, 1033-1035. doi: 10.1094/PD-76-1033

Corona, F. M. O., Arif, M., Caasi, D., and Daniels, J. (2010). Application of helicase dependent amplification, 5' non-complementary A/T rich sequences and optimal thermodynamics during primer design for increased isothermal PCR detection. Conf. Int. Organ. Citrus Virul. 18, 70.

Crannell, Z. A., Rohrman, B., and Richards-Kortum, R. (2014). Quantification of HIV-1 DNA using real-time recombinase polymerase amplification. Anal. Chem. 86, 5615-5619. doi: 10.1021/ac5011298

Craw, P., and Balachandran, W. (2012). Isothermal nucleic acid amplification technologies for point-of-care diagnostics: a critical review. Lab Chip 12, 2469-2486. doi: 10.1039/c2lc40100b

Dai, J., Peng, H., Chen, W., Cheng, J., and Wu, Y. (2013). Development of multiplex real-time PCR for simultaneous detection of three Potyviruses in tobacco plants. J. Appl. Microbiol. 114, 502-508. doi: 10.1111/jam. 12071

Daly, P., Collier, T., and Doyle, S. (2002). PCR-ELISA detection of Escherichia coli in milk. Lett. Appl. Microbiol. 34, 222-226. doi: 10.1046/j.1472-765x.2002. 01074.x

Davari, M., Van Diepeningen, A. D., Babai-Ahari, A., Arzanlou, M., Najafzadeh, M. J., Van Der Lee, T. A. J., et al. (2012). Rapid identification of Fusarium graminearum species complex using Rolling Circle Amplification (RCA). J. Microbiol. Methods 89, 63-70. doi: 10.1016/j.mimet.2012. 01.017

Deangelis, M. M., Wang, D. G., and Hawkins, T. L. (1995). Solid-phase reversible immobilization for the isolation of Pcr products. Nucleic Acids Res. 23, 4742-4743. doi: 10.1093/nar/23.22.4742

Diep, D., Plongthongkum, N., Gore, A., Fung, H. L., Shoemaker, R., and Zhang, K. (2012). Library-free methylation sequencing with bisulfite padlock probes. Nat. Methods 9, 270-272. doi: 10.1038/nmeth.1871

Duan, Y. B., Ge, C. Y., Zhang, X. K., Wang, J. X., and Zhou, M. G. (2014). A rapid detection method for the plant pathogen Sclerotinia sclerotiorum based on loopmediated isothermal amplification (LAMP). Australas. Plant Pathol. 43, 61-66. doi: 10.1007/s13313-013-0239-6

Eckert, C., Holscher, E., Petit, A., Lalande, V., and Barbut, F. (2014). Molecular test based on isothermal helicase-dependent amplification for detection of the clostridium difficile toxin a gene. J. Clin. Microbiol. 52, 2386-2389. doi: 10.1128/ JCM.00353-14

Faizul Rahman, S., Nor Amalina, Z., Asma, I., and Aziah, I. (2014). Asymmetric helicase-dependent amplification combined with lateral flow assay (HDA-LFA) for the detection of S. Paratyphi A. Asian Pac. J. Trop. Dis. 4, 243. doi: 10.1016/ S2222-1808(14)60551-X

Ferguson, B. S., Buchsbaum, S. F., Swensen, J. S., Hsieh, K., Lou, X. H., and Soh, H. T. (2009). Integrated microfluidic electrochemical DNA sensor. Anal. Chem. 81, 6503-6508. doi: 10.1021/ac900923e

Fire, A., and Xu, S. Q. (1995). Rolling replication of short DNA circles. Proc. Natl. Acad. Sci. U.S.A. 92, 4641-4645. doi: 10.1073/pnas.92.10.4641

Franken, A. A. J. M., Zilverentant, J. F., Boonekamp, P. M., and Schots, A. (1992). Specificity of polyclonal and monoclonal-antibodies for the identification of Xanthomonas-Campestris Pv Campestris. Netherlands J. Plant Pathol. 98, 8194. doi: 10.1007/BF01996321

Fukuta, S., Takahashi, R., Kuroyanagi, S., Ishiguro, Y., Miyake, N., Nagai, H., et al. (2014). Development of loop-mediated isothermal amplification assay for the detection of Pythium myriotylum. Lett. Appl. Microbiol. 59, 49-57. doi: 10.1111/ lam. 12244

Gill, P., Alvandi, A. H., Abdul-Tehrani, H., and Sadeghizadeh, M. (2008). Colorimetric detection of Helicobacter pylori DNA using isothermal helicasedependent amplification and gold nanoparticle probes. Diagn. Microbiol. Infect. Dis. 62, 119-124. doi: 10.1016/j.diagmicrobio.2008.05.003

Gill, P., Amini, M., Ghaemi, A., Shokouhizadeh, L., Abdul-Tehrani, H., Karami, A., et al. (2007). Detection of Helicobacter pylori by enzyme-linked immunosorbent assay of thermophilic helicase-dependent isothermal DNA amplification. Diagn. Microbiol. Infect. Dis. 59, 243-249. doi: 10.1016/j.diagmicrobio.2007. 05.005

Gill, P., and Ghaemi, A. (2008). Nucleic acid isothermal amplification technologies - A review. Nucleosides Nucleotides Nucleic Acids 27, 224-243. doi: $10.1080 / 15257770701845204$
Gillespie, S. H., Mchugh, T. D., and Newport, L. E. (1997). Specificity of IS6110based amplification assays for Mycobacterium tuberculosis complex. J. Clin. Microbiol. 35, 799-800.

Gorris, M. T., Alarcon, B., Lopez, M. M., and Cambra, M. (1994). Characterization of monoclonal antibodies specific for Erwinia carotovora subsp. atroseptica and comparison of serological methods for its sensitive detection on potato tubers. Appl. Environ. Microbiol. 60, 2076-2085.

Guatelli, J. C., Whitfield, K. M., Kwoh, D. Y., Barringer, K. J., Richman, D. D., and Gingeras, T. R. (1990). Isothermal, in vitro amplification of nucleic-acids by a multienzyme reaction modeled after retroviral replication. Proc. Natl. Acad. Sci. U.S.A. 87, 1874-1878. doi: 10.1073/pnas.87.5.1874

Gusev, Y., Sparkowski, J., Raghunathan, A., Ferguson, H., Montano, J., Bogdan, N., et al. (2001). Rolling circle amplification - A new approach to increase sensitivity for immunohistochemistry and flow cytometry. Am. J. Pathol. 159, 63-69. doi: 10.1016/S0002-9440(10)61674-4

Hadersdorfer, J., Neumuller, M., Treutter, D., and Fischer, T. C. (2011). Fast and reliable detection of Plum pox virus in woody host plants using the Blue LAMP protocol. Ann. Appl. Biol. 159, 456-466. doi: 10.1111/j.1744-7348.2011.00510.x

Hardenbol, P., Baner, J., Jain, M., Nilsson, M., Namsaraev, E. A., Karlin-Neumann, G. A., et al. (2003). Multiplexed genotyping with sequence-tagged molecular inversion probes. Nat. Biotechnol. 21, 673-678. doi: 10.1038/nbt821

Heid, C. A., Stevens, J., Livak, K. J., and Williams, P. M. (1996). Real time quantitative PCR. Genome Res. 6, 986-994. doi: 10.1101/gr.6.10.986

Hindson, B. J., Ness, K. D., Masquelier, D. A., Belgrader, P., Heredia, N. J., Makarewicz, A. J., et al. (2011). High-throughput droplet digital PCR system for absolute quantitation of DNA copy number. Anal. Chem. 83, 8604-8610. doi: $10.1021 / \mathrm{ac} 202028 \mathrm{~g}$

Horsfall, J. G., and Cowling, E. B. (1977). Plant Disease: An Advanced Treatise. New York, NY: Academic Press.

Hsieh, K. W., Patterson, A. S., Ferguson, B. S., Plaxco, K. W., and Soh, H. T. (2012). Rapid, sensitive, and quantitative detection of pathogenic DNA at the point of care through microfluidic electrochemical quantitative loop-mediated isothermal amplification. Angew. Chem. 51, 4896-4900. doi: 10.1002/anie. 201109115

Huang, S. C., Do, J., Mahalanabis, M., Fan, A., Zhao, L., Jepeal, L., et al. (2013). Low cost extraction and isothermal amplification of DNA for infectious diarrhea diagnosis. PLOS ONE 8:e60059. doi: 10.1371/journal.pone.0060059

Ikeda, S., Tsurumaru, H., Wakai, S., Noritake, C., Fujishiro, K., Akasaka, M., et al. (2008). Evaluation of the effects of different additives in improving the DNA extraction yield and quality from Andosol. Microbes Environ. 23, 159-166. doi: 10.1264/jsme2.23.159

Ji, H. X., Yan, F., Lei, J. P., and Ju, H. X. (2012). Ultrasensitive electrochemical detection of nucleic acids by template enhanced hybridization followed with rolling circle amplification. Anal. Chem. 84, 7166-7171. doi: 10.1021/ac3015356

Kent, L., Mchugh, T. D., Billington, O., Dale, J. W., and Gillespie, S. H. (1995). Demonstration of homology between Is6110 of Mycobacterium tuberculosis and Dnas of Other Mycobacterium Spp J. Clin. Microbiol. 33, 3082-3082.

Kersting, S., Rausch, V., Bier, F. F., and Von Nickisch-Rosenegk, M. (2014). Rapid detection of Plasmodium falciparum with isothermal recombinase polymerase amplification and lateral flow analysis. Malar. J. 13:99. doi: 10.1186/1475-287513-99

Khoodoo, M. H. R., Sahin, F., and Jaufeerally-Fakim, Y. (2005). Sensitive detection of Xanthomonas axonopodis pv. dieffenbachiae on Anthurium andreanum by immunocapture-PCR (IC-PCR) using primers designed from sequence characterized amplified regions (SCAR) of the blight pathogen. Eur. J. Plant Pathol. 112, 379-390. doi: 10.1007/s10658-005-7062-z

Kobori, T., and Takahashi, H. (2014). Expanding possibilities of rolling circle amplification as a biosensing platform. Anal. Sci. 30, 59-64. doi: 10.2116/ analsci.30.59

Kokoskova, B., and Janse, J. D. (2009). Enzyme-linked immunosorbent assay for the detection and identification of plant pathogenic bacteria (in particular for Erwinia amylovora and Clavibacter michiganensis subsp. sepedonicus). Methods Mol. Biol. 508, 75-87. doi: 10.1007/978-1-59745-062-1_7

Lai, Y. M., Sun, S. Q., He, T., Schlucker, S., and Wang, Y. L. (2015). Ramanencoded microbeads for spectral multiplexing with SERS detection. RSC Adv. 5, 13762-13767. doi: 10.1039/C4RA16163G

Laing, S., Gracie, K., and Faulds, K. (2016). Multiplex in vitro detection using SERS. Chem. Soc. Rev. 45, 1901-1918. doi: 10.1039/c5cs00644a 
Laitinen, R., Malinen, E., and Palva, A. (2002). PCR-ELISA I: application to simultaneous analysis of mixed bacterial samples composed of intestinal species. Syst. Appl. Microbiol. 25, 241-248.

Lau, H. Y., Palanisamy, R., Trau, M., and Botella, J. R. (2014). Molecular inversion probe: a new tool for highly specific detection of plant pathogens. PLOS ONE 9:e111182. doi: 10.1371/journal.pone.0111182

Lau, H. Y., Wang, Y., Wee, E. J., Botella, J. R., and Trau, M. (2016). Field demonstration of a multiplexed point-of-care diagnostic platform for plant pathogens. Anal. Chem. 88, 8074-8081. doi: 10.1021/acs.analchem. 6b01551

Lau, H. Y., Wu, H., Wee, E. J., Trau, M., Wang, Y., and Botella, J. R. (2017). Specific and sensitive isothermal electrochemical biosensor for plant pathogen DNA detection with colloidal gold nanoparticles as probes. Sci. Rep. 7:38896. doi: $10.1038 /$ srep 38896

Lee, M.-F., Chen, J.-Y., and Peng, C.-F. (2014). Study on the LAMPPCR-hybridization-thermal melt-ELISA method for molecular detection of multidrug resistance in Mycobacterium tuberculosis isolates. Biomark. Genom. Med. 6, 126-132. doi: 10.1016/j.bgm.2014.05.002

Li, X. J., Luo, J. F., Xiao, P. F., Shi, X. L., Tang, C., and Lu, Z. H. (2009). Genotyping of multiple single nucleotide polymorphisms with hyperbranched rolling circle amplification and microarray. Clin. Chim. Acta 399, 40-44. doi: 10.1016/j.cca. 2008.08.012

Lin, S. R., Wang, W. Y., Palm, C., Davis, R. W., and Juneau, K. (2010). A molecular inversion probe assay for detecting alternative splicing. BMC Genomics 11:712. doi: 10.1186/1471-2164-11-712

Lizardi, P. M., Huang, X. H., Zhu, Z. R., Bray-Ward, P., Thomas, D. C., and Ward, D. C. (1998). Mutation detection and single-molecule counting using isothermal rolling-circle amplification. Nat. Genet. 19, 225-232. doi: 10.10 $38 / 898$

Lutz, S., Weber, P., Focke, M., Faltin, B., Hoffmann, J., Muller, C., et al. (2010). Microfluidic lab-on-a-foil for nucleic acid analysis based on isothermal recombinase polymerase amplification (RPA). Lab Chip 10, 887-893. doi: 10. $1039 / \mathrm{b} 921140 \mathrm{c}$

Macario, A. J. L., and Conway de Macario, E. (1985). Monoclonal Antibodies Against Bacteria. Orlando, FL: Academic Press.

Mahalanabis, M., Do, J., Almuayad, H., Zhang, J. Y., and Klapperich, C. M. (2010). An integrated disposable device for DNA extraction and helicase dependent amplification. Biomed. Microdevices 12, 353-359. doi: 10.1007/s10544-0099391-8

Maiti, K. K., Samanta, A., Vendrell, M., Soh, K. S., Olivo, M., and Chang, Y. T. (2011). Multiplex cancer cell detection by SERS nanotags with cyanine and triphenylmethine Raman reporters. Chem. Commun. 47, 3514-3516. doi: 10. $1039 / \mathrm{c} 0 \mathrm{cc} 05265 \mathrm{e}$

Malin, E. M., Roth, D. A., and Belden, E. L. (1983). Indirect immunofluorescent staining for detection and identification of Xanthomonas-Campestris $\mathrm{Pv}$ phaseoli in naturally infected bean seed. Plant Dis. 67, 645-647. doi: 10.1094/ PD-67-645

Markoulatos, P., Siafakas, N., and Moncany, M. (2002). Multiplex polymerase chain reaction: a practical approach. J. Clin. Lab. Anal. 16, 47-51. doi: 10.1002/ jcla.2058

Massart, S., Olmos, A., Jijakli, H., and Candresse, T. (2014). Current impact and future directions of high throughput sequencing in plant virus diagnostics. Virus Res. 188, 90-96. doi: 10.1016/j.virusres.2014.03.029

Mechanic, L. E., Frankel, B. A., and Matson, S. W. (2000). Escherichia coli MutL loads DNA helicase II onto DNA. J. Biol. Chem. 275, 38337-38346. doi: 10.1074/ jbc.M006268200

Mekuria, T. A., Zhang, S. L., and Eastwell, K. C. (2014). Rapid and sensitive detection of Little cherry virus 2 using isothermal reverse transcriptionrecombinase polymerase amplification. J. Virol. Methods 205, 24-30. doi: 10. 1016/j.jviromet.2014.04.015

Merighi, M., Sandrini, A., Landini, S., Ghini, S., Girotti, S., Malaguti, S., et al. (2000). Chemiluminescent and colorimetric detection of Erwinia amylovora by immunoenzymatic determination of PCR amplicons from plasmid pEA29. Plant Dis. 84, 49-54. doi: 10.1094/PDIS.2000.84.1.49

Miotke, L., Lau, B. T., Rumma, R. T., and Ji, H. P. (2014). High sensitivity detection and quantitation of DNA copy number and single nucleotide variants with single color droplet digital PCR. Anal. Chem. 86, 2618-2624. doi: 10.1021/ ac403843j
Moskovits, M. (2010). SPECTROSCOPY Expanding versatility. Nature 464, $357-$ 357. doi: $10.1038 / 464357 \mathrm{a}$

Murphy, K., Travers, P., Walport, M., and Janeway, C. (2012). Janeway's Immunobiology. New York, NY: Garland Science.

Nagamine, K., Kuzuhara, Y., and Notomi, T. (2002). Isolation of single-stranded DNA from loop-mediated isothermal amplification products. Biochem. Biophys. Res. Commun. 290, 1195-1198. doi: 10.1006/bbrc.2001.6334

Najafzadeh, M. J., Sun, J., Vicente, V. A., and De Hoog, G. S. (2011). Rapid identification of fungal pathogens by rolling circle amplification using Fonsecaea as a model. Mycoses 54, E577-E582. doi: 10.1111/j.1439-0507.2010. 01995.x

Nallur, G., Luo, C. H., Fang, L. H., Cooley, S., Dave, V., Lambert, J., et al. (2001). Signal amplification by rolling circle amplification on DNA microarrays. Nucleic Acids Res. 29, e118. doi: 10.1093/nar/29.23.e118

Narayanasamy, P. (2011). Microbial Plant Pathogens-Detection and Disease Diagnosis. Dordrecht: Springer.

Ng, B. Y. C., Wee, E. J. H., West, N. P., and Trau, M. (2015). Rapid DNA detection of Mycobacterium tuberculosis-towards single cell sensitivity in point-of-care diagnosis. Sci. Rep. 5, 15027. doi: 10.1007/978-1-4939-2172-0_3

Notomi, T., Okayama, H., Masubuchi, H., Yonekawa, T., Watanabe, K., Amino, N., et al. (2000). Loop-mediated isothermal amplification of DNA. Nucleic Acids Res. 28, E63. doi: 10.1093/nar/28.12.e63

Novakova, S., Klaudiny, J., Kollerova, E., and Subr, Z. W. (2006). Expression of a part of the Potato virus A non-structural protein P3 in Escherichia coli for the purpose of antibody preparation and P3 immunodetection in plant material. J. Virol. Methods 137, 229-235. doi: 10.1016/j.jviromet.2006.06.020

Nowrouzian, F. L., Adlerberth, I., and Wold, A. E. (2009). High frequency of false-positive signals in a real-time PCR-based "Plus/Minus" assay. APMIS 117, 68-72. doi: 10.1111/j.1600-0463.2008.00010.x

Nutman, T. B., Zimmerman, P. A., Kubofcik, J., and Kostyu, D. D. (1994). A universally applicable diagnostic-approach to filarial and other infections. Parasitol. Today 10, 239-243. doi: 10.1016/0169-4758(94)90127-9

Piepenburg, O., Williams, C. H., Stemple, D. L., and Armes, N. A. (2006). DNA detection using recombination proteins. PLOS Biol. 4:e204. doi: 10.1371/ journal.pbio.0040204

Price, J. A., Smith, J., Simmons, A., Fellers, J., and Rush, C. M. (2010). Multiplex real-time RT-PCR for detection of Wheat streak mosaic virus and Triticum mosaic virus. J. Virol. Methods 165, 198-201. doi: 10.1016/j.jviromet.2010. 01.019

Punja, Z. K., De Boer, S., and Sanfaçon, H. L. N. (2007). Biotechnology and Plant Disease Management. Cambridge, MA: Cabi Publishing. doi: 10.1079/ 9781845932886.0000

Ravan, H., and Yazdanparast, R. (2012). Development and evaluation of a loopmediated isothermal amplification method in conjunction with an enzymelinked immunosorbent assay for specific detection of Salmonella serogroup D. Anal. Chim. Acta 733, 64-70. doi: 10.1016/j.aca.2012.04.034

Rohrman, B. A., and Richards-Kortum, R. R. (2012). A paper and plastic device for performing recombinase polymerase amplification of HIV DNA. Lab Chip 12, 3082-3088. doi: 10.1039/c2lc40423k

Rott, M., Xiang, Y., Boyes, I., Belton, M., Saeed, H., Kesanakurti, P., et al. (2017). Application of next generation sequencing for diagnostic testing of tree fruit viruses and viroids. Plant Dis. 101, 1489-1499. doi: 10.1094/PDIS-03-170306-RE

Russell, C., Welch, K., Jarvius, J., Cai, Y. X., Brucas, R., Nikolajeff, F., et al. (2014). Gold nanowire based electrical DNA detection using rolling circle amplification. ACS Nano 8, 1147-1153. doi: 10.1021/nn4058825

Santiago-Felipe, S., Tortajada-Genaro, L. A., Puchades, R., and Maquieira, A. (2014). Recombinase polymerase and enzyme-linked immunosorbent assay as a DNA amplification-detection strategy for food analysis. Anal. Chim. Acta 811, 81-87. doi: 10.1016/j.aca.2013.12.017

Schlucker, S. (2009). SERS microscopy: nanoparticle probes and biomedical applications. Chemphyschem 10, 1344-1354. doi: 10.1002/cphc.200900119

Schlucker, S. (2014). Surface-enhanced raman spectroscopy: concepts and chemical applications. Angew. Chem. 53, 4756-4795. doi: 10.1002/anie.201205748

Schubert, J., Habekuss, A., Kazmaier, K., and Jeske, H. (2007). Surveying cerealinfecting geminiviruses in Germany - Diagnostics and direct sequencing using rolling circle amplification. Virus Res. 127, 61-70. doi: 10.1016/j.virusres.2007. 03.018 
Sharma, B., Frontiera, R. R., Henry, A. I., Ringe, E., and Van Duyne, R. P. (2012). SERS: Materials, applications, and the future. Mater. Today 15, 16-25. doi: 10.1016/S1369-7021(12)70017-2

Shindo, M., Dibisceglie, A. M., Silver, J., Limjoco, T., Hoofnagle, J. H., and Feinstone, S. M. (1994). Detection and quantitation of Hepatitis-C Virus-Rna in serum using the polymerase chain-reaction and a colorimetric enzymatic detection system. J. Virol. Methods 48, 65-72. doi: 10.1016/0166-0934(94) 90089-2

Sint, D., Raso, L., and Traugott, M. (2012). Advances in multiplex PCR: balancing primer efficiencies and improving detection success. Methods Ecol. Evol. 3, 898-905. doi: 10.1111/j.2041-210X.2012.00215.x

Slawiak, M., Van Doorn, R., Szemes, M., Speksnijder, A. G. C. L., Waleron, M., Van Der Wolf, J. M., et al. (2013). Multiplex detection and identification of bacterial pathogens causing potato blackleg and soft rot in Europe, using padlock probes. Ann. Appl. Biol. 163, 378-393. doi: 10.1111/aab.12075

Somai, B. M., Keinath, A. P., and Dean, R. A. (2002). Development of PCR-ELISA for detection and differentiation of Didymella bryoniae from related Phoma species. Plant Dis. 86, 710-716. doi: 10.1094/PDIS.2002.86.7.710

Strange, R. (2012). Almost 40 Per Cent of Worldwide Crops Lost to Diseases. The Crop Site. Available at: http://www.thecropsite.com/articles/1202/almost40-per-cent-of-worldwide-crops-lost-to-diseases/

Szemes, M., Bonants, P., De Weerdt, M., Baner, J., Landegren, U., and Schoen, C. D. (2005). Diagnostic application of padlock probes-multiplex detection of plant pathogens using universal microarrays. Nucleic Acids Res. 33, e70. doi: 10.1093/nar/gni069

Teitelbaum, D., Aharoni, R., Sela, M., and Arnon, R. (1991). Cross-reactions and specificities of monoclonal antibodies against myelin basic protein and against the synthetic copolymer 1. Proc. Natl. Acad. Sci. U.S.A. 88, 9528-9532. doi: 10.1073/pnas.88.21.9528

Thornton, C. R. (2009). Production of monoclonal antibodies to plant pathogens. Methods Mol. Biol. 508, 63-74. doi: 10.1007/978-1-59745-062-1 6

Tian, Y. L., Zhao, Y. Q., Xu, R., Liu, F. Q., Hu, B. S., and Walcott, R. R. (2014) Simultaneous detection of Xanthomonas oryzae pv. oryzae and $\mathrm{X}$. oryzae pv. oryzicola in rice seed using a padlock probe-based assay. Phytopathology 104, 1130-1137. doi: 10.1094/PHYTO-10-13-0274-R

Tomita, N., Mori, Y., Kanda, H., and Notomi, T. (2008). Loop-mediated isothermal amplification (LAMP) of gene sequences and simple visual detection of products. Nat. Protoc. 3, 877-882. doi: 10.1038/nprot.2008.57

Tomlinson, J. A., Boonham, N., and Dickinson, M. (2010a). Development and evaluation of a one-hour DNA extraction and loop-mediated isothermal amplification assay for rapid detection of phytoplasmas. Plant Pathol. 59, 465-471. doi: 10.1111/j.1365-3059.2009.02233.x

Tomlinson, J. A., Dickinson, M., Hobden, E., Robinson, S., Giltrap, P. M., and Boonham, N. (2010b). A five-minute DNA extraction method for expedited detection of Phytophthora ramorum following prescreening using Phytophthora spp. lateral flow devices. J. Microbiol. Methods 81, 116-120. doi: 10.1016/j.mimet.2010.02.006

Tomlinson, J. A., Dickinson, M. J., and Boonham, N. (2010c). Detection of Botrytis cinerea by loop-mediated isothermal amplification. Lett. Appl. Microbiol. 51, 650-657. doi: 10.1111/j.1472-765X.2010.02949.x

Tomlinson, J. A., Dickinson, M. J., and Boonham, N. (2010d). Rapid detection of Phytophthora ramorum and P. kernoviae by two-minute DNA extraction followed by isothermal amplification and amplicon detection by generic lateral flow device. Phytopathology 100, 143-149. doi: 10.1094/PHYTO-100-2-0143

van Doorn, R., Szemes, M., Bonants, P., Kowalchuk, G. A., Salles, J. F., Ortenberg, E., et al. (2007). Quantitative multiplex detection of plant pathogens using a novel ligation probe-based system coupled with universal, highthroughput real-time PCR on OpenArrays (TM). BMC Genomics 8:276. doi: 10.1186/1471-2164-8-276

Vincelli, P., and Tisserat, N. (2008). Nucleic acid-based pathogen detection in applied plant pathology. Plant Dis. 92, 660-669. doi: 10.1146/annurev-phyto080508-081916

Vincent, M., Xu, Y., and Kong, H. M. (2004). Helicase-dependent isothermal DNA amplification. EMBO Rep. 5, 795-800. doi: 10.1038/sj.embor.7400200
Wang, Y., Cottman, M., and Schiffman, J. D. (2012). Molecular inversion probes: a novel microarray technology and its application in cancer research. Cancer Genet. 205, 341-355. doi: 10.1016/j.cancergen.2012. 06.005

Wang, Y. K., Moorhead, M., Karlin-Neumann, G., Falkowski, M., Chen, C. N., Siddiqui, F., et al. (2005). Allele quantification using molecular inversion probes (MIP). Nucleic Acids Res. 33, e183. doi: 10.1093/nar/gni177

Wang, Y. L., and Schlucker, S. (2013). Rational design and synthesis of SERS labels. Analyst 138, 2224-2238. doi: 10.1039/c3an36866a

Wang, Y. L., Wee, E. J. H., and Trau, M. (2015). Highly sensitive DNA methylation analysis at $\mathrm{CpG}$ resolution by surface-enhanced Raman scattering via ligase chain reaction. Chem. Commun. 51, 10953-10956. doi: 10.1039/c5cc0 $3921 \mathrm{e}$

Ward, E., Foster, S. J., Fraaije, B. A., and Mccartney, H. A. (2004). Plant pathogen diagnostics: immunological and nucleic acid-based approaches. Ann. Appl. Biol. 145, 1-16. doi: 10.3109/1040841X.2010.489892

Watthanapanpituck, K., Kiatpathomchai, W., Chu, E., and Panvisavas, N. (2014). Identification of human DNA in forensic evidence by loop-mediated isothermal amplification combined with a colorimetric gold nanoparticle hybridization probe. Int. J. Legal Med. 128, 923-931. doi: 10.1007/s00414-0141018-9

Wee, E. J. H., Lau, H. Y., Botella, J. R., and Trau, M. (2015). Re-purposing bridging flocculation for on-site, rapid, qualitative DNA detection in resource-poor settings. Chem. Commun. 51, 5828-5831. doi: 10.1039/c4cc10068a

Wetzel, T., Candresse, T., Macquaire, G., Ravelonandro, M., and Dunez, J. (1992). A highly sensitive immunocapture polymerase chain-reaction method for plum pox potyvirus detection. J. Virol. Methods 39, 27-37. doi: 10.1016/01660934(92)90122-T

White, T. J., Arnheim, N., and Erlich, H. A. (1989). The polymerase chain-reaction. Trends Genet. 5, 185-189. doi: 10.1016/0168-9525(89)90073-5

Withers, S., Gongora-Castillo, E., Gent, D., Thomas, A., Ojiambo, P. S., and Quesada-Ocampo, L. M. (2016). Using next-generation sequencing to develop molecular diagnostics for pseudoperonospora cubensis, the cucurbit downy mildew pathogen. Phytopathology 106, 1105-1116. doi: 10.1094/PHYTO-1015-0260-FI

Wong, M. L., and Medrano, J. F. (2005). Real-time PCR for mRNA quantitation. Biotechniques 39, 75-85. doi: 10.2144/05391RV01

Yager, P., Edwards, T., Fu, E., Helton, K., Nelson, K., Tam, M. R., et al. (2006). Microfluidic diagnostic technologies for global public health. Nature 442 412-418. doi: 10.1038/nature05064

Zhang, S. L., Ravelonandro, M., Russell, P., Mcowen, N., Briard, P., Bohannon, S., et al. (2014). Rapid diagnostic detection of plum pox virus in Prunus plants by isothermal AmplifyRP (R) using reverse transcriptionrecombinase polymerase amplification. J. Virol. Methods 207, 114-120. doi: 10.1016/j.jviromet.2014.06.026

Zhang, X., Zhang, H., Pu, J. J., Qi, Y. X., Yu, Q. F., Xie, Y. X., et al. (2013). Development of a real-time fluorescence loop-mediated isothermal amplification assay for rapid and quantitative detection of Fusarium oxysporum f. sp cubense tropical race 4 in soil. PLOS ONE 8:e82841. doi: 10.1371/journal. pone.0082841

Zou, Y., Mason, M. G., Wang, Y., Wee, E., Turni, C., Blackall, P., et al. (2017). Nucleic acid purification from plants, animals and microbes in under 30 seconds. PLOS Biol. 15:e2003916.

Conflict of Interest Statement: The authors declare that the research was conducted in the absence of any commercial or financial relationships that could be construed as a potential conflict of interest.

Copyright (c) 2017 Lau and Botella. This is an open-access article distributed under the terms of the Creative Commons Attribution License (CC BY). The use, distribution or reproduction in other forums is permitted, provided the original author(s) or licensor are credited and that the original publication in this journal is cited, in accordance with accepted academic practice. No use, distribution or reproduction is permitted which does not comply with these terms. 